特集・容器包装リサイクル法への取り組み

\title{
PET ボトルリサイクルっ現状と課題
}

中西武*

1.PET ボトル協議会は廃棄物独自の問題の適 切な対応を図るため, 1982年10月に設立された。

1970年代後半のガラス瓶の破瓶問題から，落とし ても割れない安全な容器として登場し，1977年に醬 油ボトルに, 1982年には清涼飲料容器として認めら れた。現在では清涼飲料に $70 \%$ ，その他アルコール 飲料, 調味料, 洗剤等へと幅広い用途に使われている.

\section{PET ボトル資源化のための法則}

1993年 6 月の再生資源の利用の促進に関する法律 の政令改正により PET ボトルは「第 2 種指定製品」 に指定され, ボトルの回収と再生を早急に実施でき る体制の整備が求められた。

1993年 9 月, 各社 ${ }^{11}$ は PET ボトル協議会に資金を 投入し栃木県南河内町に本格的な処理工場を建設 し, 一般廃棄物からの PET ボトルの再生処理工場

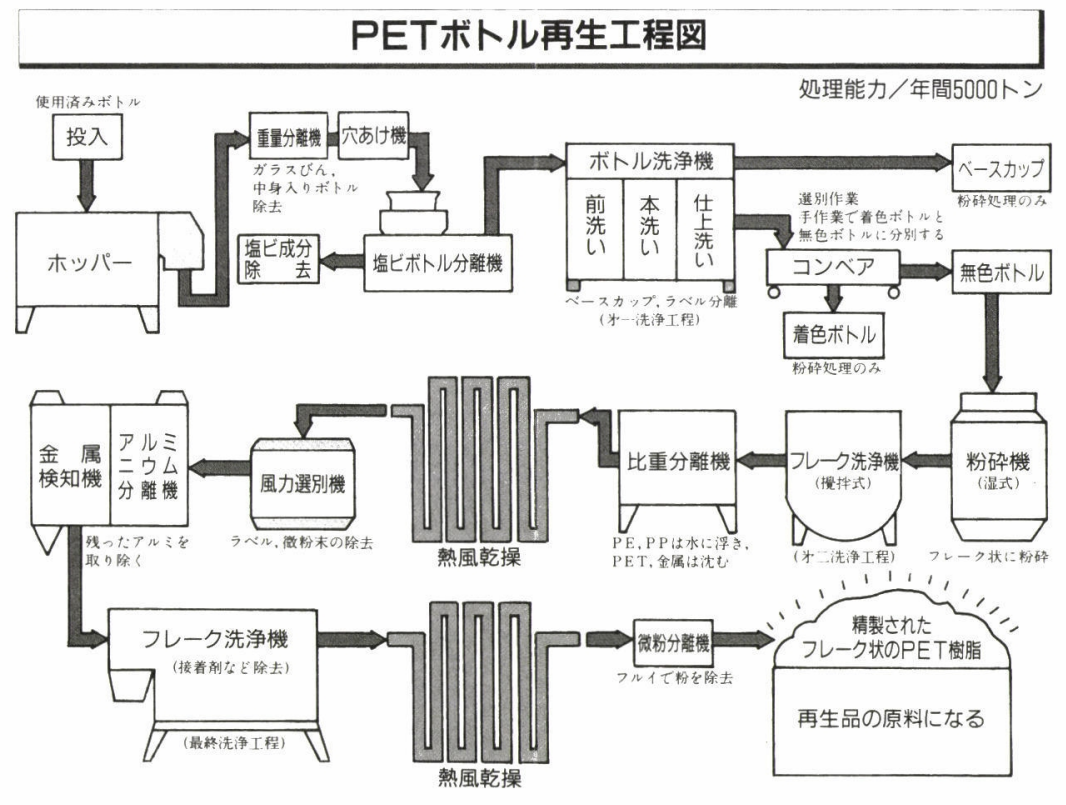

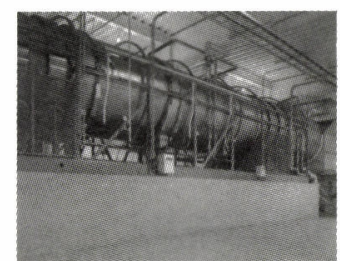

ポトル洗浄機

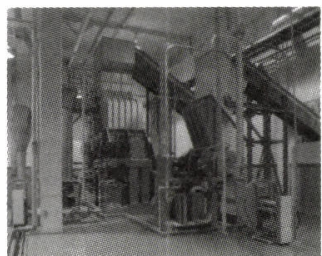

粉砕機

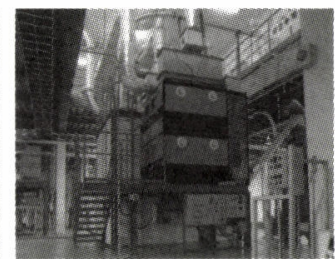

アルミニウム分離機

*PET ボトル協議会 Takeshi NAKANISHI 
を日本で初めてスタートさせた. 1995年 6 月には「容 器包装に係わる分別収集及び再商品化の促進に関す る法律」が成立公布された，基本的には地方公共団 体，消費者，事業者の役割分担を明確にする，つま り<資源の循環型社会 >に向けての行動が求められ た。市町村には分別収集（プラスチックの殆どは焼 却や埋立が大部分である）を，消費者には市町村の 分別収集にへの協力を, 事業者には再商品化に対す る責任をと, この 3 つの責任を求め, そのトライア ングルでいずれの責任もお互い試行する事によって 効果が上がる事が求められている.

\section{3. 第 2 種指定 PET ボトル自主設計 ガイドラインを設定する.}

1992年 PET ボトル協議会と全国清涼飲料工業会 はリサイクルがより容易になる商品の自主ガイドラ インを設定し，関係業界もリサイクルのしやすい PET ボトル作りに努めている. PVCラベルから $\mathrm{P}$ $\mathrm{E}, \mathrm{OPS}$ 変更した。 またアルミキャップからポリ エチレンキャップへの変換へと素材の切り替えが進 められている。海外からの輸入についてもも PVC ボトルから PET ボトルへの切り替えが急ピッチで 進められている.中でも PVC ボトルの混入は再利 用品の作成のために大きな障害となっており, 我々 の工場の中でも 1 本の塩ビボトルを発見するために 高価な検知機を導入している. 従って分別回収時に 回収される容器の品質の安定こそが, いかにコスト の安いリサイクルにつながつてゆくための大切な要 素になっているかという事を理解してほしいと思っ ている.

\section{4. 回収と収集システムについて}

使用済み PET ボトルの回収方法として, 自治体 に依る分別回収ルートと店頭回収があるが，実績か ら申して自治体による回収が圧倒的に多い，再商品 化工場が健全な事業として成立するためには，再商 品化能力と分別収集量との適合が最重要課題であ り，このような点から自治体等に対する分別収集の 働きかけには，特に力を入れて取り組んでいる. 昨年末で117自治体の参加があり人口対象で 1004 万人となっている. 又1996年には50自治体が増えて 167自治体になる予定である.量的にまとまりやすく 回収効率が良く, 消費者の負担も軽くて協力を得や すいのは自治体を中心とした分別回収方法であると
考えている.マテリアルリサイクルを進める上では, 原料としての回収ボトルの品質を確保するため分別 回収を徹底し,かつ大量回収することが重要である。 この方法が污れもなく，他種材料の混入もなく，量 的にまとまりやすく総合的で効率が良い. 自治体は 現状の回収方法から他の方法に変えたり現状に負加 するとお金がかかるという意見もあるが，埋立する ための運賃と埋立地の寿命等を計算して, リサイク ルが国の云う循環型社会に添うか否かを検討しても 良いのではないかと思う.私共も $8,000 \mathrm{t}$ 能力の工場 で4,000 t の処理ではランニングコストは赤字であ るが，然し国の施策に対し懸命に努力をして循環型 社会の形成，特に経済的に循環してゅく事を早く実 現したいと思っている.PET ボトルから非食品ボト ル．近い将来飲料ボトルにそして第 2 次利用として シート製品加工品に, 第 3 次として繊維製品に 3 段 階リサイクルを実現できるようにと，関連業界が一 致協力してリサイクルの用途開発を行っている事を ご理解いただきたいものである.

\section{PET ボトルの将来の見通し}

業界では全国に打ける PET ボトルの回収が自治 体及び消費者の同意を得られたとして 2005 年の 10 年 後に199,000 t （年率 $3 \%$ の成長として）に37\%で 74,000 t のリサイクルをする事を発表した。一工場 $8,000 \mathrm{t}$ の能力の工場が全国 8 所に必要である.し かし工場の設立の条件として消費者や自治体をまと めることができる可能性の高い処，工場建設に住民 や自治体の同意が得られる見通しがある処等々の条 件をクリアーせねばならず，今迄の数々の経験から 少なくとも $3 \sim 4$ 年かけて交渉を重ねてゆかなけれ ばならない.

PET 協議会は関東の第一工場を杤木に, 関西の第 一工場を三重県に, 中国地区の工場を現在交涉中, 九州地区も現在交涉中であり, 関東第 2 工場につい ては現在物色中である. 従って平成 10 年迄に 4 工場 を稼働させると予定して活動を続行中である。この 点消費者と自治体のご支援を是非お願い申しあげた い. 少なくともトライアングルの 1 辺の役目を業界 は果たさねばならぬと実感している。

\section{6. 工場建設計画の概要}

過去 3 年に亘り栃木工場にて PET ボトルの処理 工場を稼㗢してきたが，多くの問題点に遭遇してき 
た. 勿論リサイクル法施行前なので回収した製品の 品質の基準についても，キャップをとる，洗って出 すとの 2 点のみお願いをしてきたが不燃物として回 収されたものの中からピックアップした製品, 色々 のものを手がけてきた，従って，分別回収する場合 と不燃物から取り出す場合とではまったく污れの度 合が異なり，処理も簡単にはいかない.しかし不燃 物からの回収を駄目だとすると量の点で大変な不足 となり，量を確保するために殆どの品質を受け入れ てきた。しかしその結果キャップのついたものが30 \%以下にならず，アルミを除去するのに多額の設備 が必要となり，それでいて出来上がりの商品の発売 価格は低いものになってしまう. 従って第 2 工場は 今までの経験をとり入れこの点を改善しているが, 少なくともキャップを外して貪う事だけは徹底して してほしいと要望している。

又自治体回収のおり，足で潰してもらうと，1／ 3 に減容化され, 又さらに自治体でプレスをすると $1 / 10$ になる.この点も是非お願いをしておきたい
事である。

この, PET ボトルの回収という点で, 私が実に感 激した市がある.一つの例として紹介すると，栃木 県大田原市（人口 51,600 人）の場合，市の担当者が 市内20校と相談をした結果, PET ボトルを回収する のに子供達の力を借りると同時に教育の一環として 取り組んでみようという結論に至った所から出発し た。

PET ボトルを 1 本持参した人に対し,市から 5 円 の奨励金を出し，その費用を学校が生徒にわかるよ うに花壇の用具とかその他のものの購入にあて, 常 に生徒が自分達の成果を目に見えるような形にする という事が考えられた.さらに, 近所の人も学校が 設置した場所に持って来られるようになっていた。 集まっている製品はキャップが1ケもついておら ず，洉れたボトルもなく，そのことを情熱を込めて 私共に話してくれた先生を忘れることはできない. 生徒が家庭から持ってきたもので225,000本を集め た. 私共の推計によれば， $22 \%$ 位のリサイクル率に

\section{指定袋に名前を書くのは}

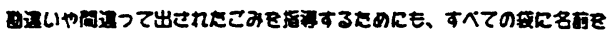

ペットボトル

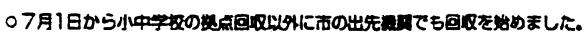

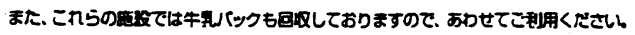

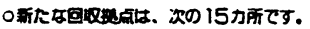

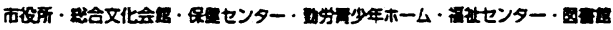

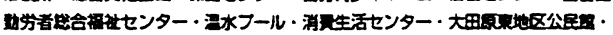

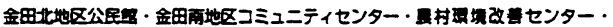

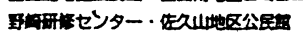

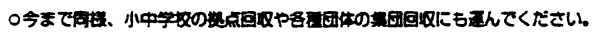

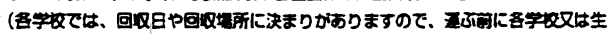
活最まで同い合わせください) ・キャッフをはすして

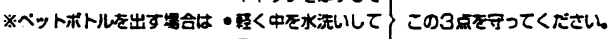
・足でみつルして
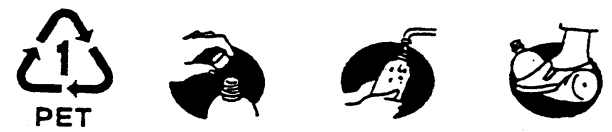

補助金制度

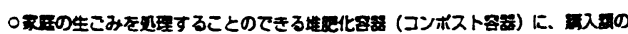
2分の1 (阳 5.000円) の助金を出してあります.

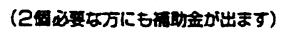

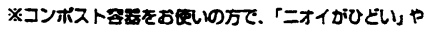

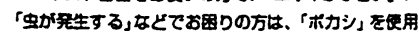

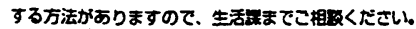

\section{大田原市民のルールです}

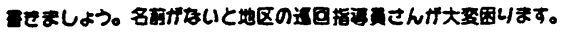

清擩センターから

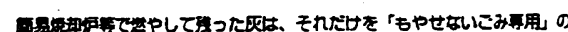

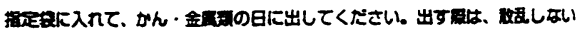

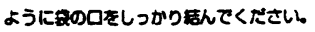

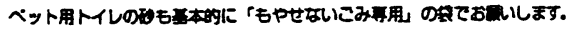

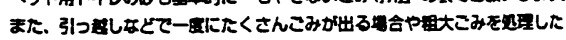

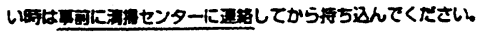

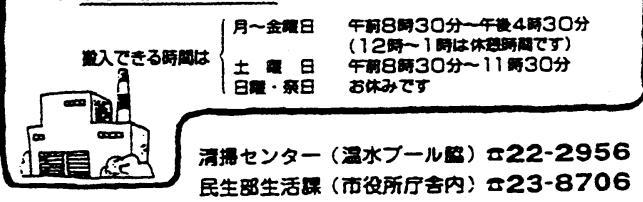

栃木県大田原市の公報 
なります．ありがたい事で私共も先生と生徒に教え られた例である。

従って私どもも自治体をまわってリサイクルへの 協力をお願いして歩くことも必要だと思っている.

特に関西地区は静岡県から兵庫県まで約820市町 村あるが, 今のところ国の調査では，そのうち137市 町村が参加し681万人が対象となっているいう事で ある.そこでまず $30 \%$ 回収率とすると $2,200 \mathrm{t}$ 位であ り，処理工場としては，30\%の稼働率にしかならず, 何とか消費者と自治体による, 数多くのリサイクル への参加支援をお願いしたいと思うものである．関 西工場は平成 8 年 4 月から資材の受け入れを始め, 蓄積をしながら平成 9 年 4 月の稼働に向けて準備中 である。

平成 9 年の早い時期に $5,000 \mathrm{t} \sim 6,000 \mathrm{t}$ の収集が できるよう重ねてお願いをしたい，関西工場では特 に再商品化事業は，廃棄物投入処理量の $43 \%$ をペレ ット即ちボトルの再利用を主とし，50\%をフレーク 製品，再利用品としてシート成形加工製品と繊維製 品に，そして $7 \%$ は色物の瀻維製品として再利用し ていけるようになっている。

大量消費では土木資材湧水パネル等の用途開発を 積極的に行っている．消費者のご期待に添えるよう に努力して参る事を約束する．現在 PET を使用し ている量を表として右に揭げる，なお，米国や欧州 の表も参考にして比較していただければ幸いであ る.
注 1 ）：PET ボトル協議会は正会員の樹脂メーカー, 成形メ一 カーなど19社, 长の他商社, 団体などの賛助会員や学識 経験者からなる特別会員によって構成されている。

日本におけるボトル用 PET 樹脂の用途別需要

(単位：トン)

\begin{tabular}{|c|c|c|c|c|c|c|}
\hline \multirow[b]{3}{*}{ 食 } & 用 & \multirow{2}{*}{\begin{tabular}{|c|}
1991 \\
12,500
\end{tabular}} & \multirow{2}{*}{$\begin{array}{c}1992 \\
13,200\end{array}$} & \multirow{2}{*}{$\begin{array}{c}1993 \\
13,300\end{array}$} & \multirow{2}{*}{\begin{tabular}{|c|}
1994 \\
13,468
\end{tabular}} & \multirow{2}{*}{$\begin{array}{c}1995 \\
13,491\end{array}$} \\
\hline & 醬 & & & & & \\
\hline & 醬油を除く調味料 & 1,722 & 3,746 & 5,221 & 7,348 & 9,674 \\
\hline \multirow{3}{*}{$\begin{array}{l}\text { 品 } \\
\text { 用 }\end{array}$} & 食用 & 1,642 & 1,899 & 2,195 & 1,689 & 1,373 \\
\hline & 酒 & 5,739 & 5,766 & 7,734 & 10,133 & 9,788 \\
\hline & 清 涼 飲 料 & 89,383 & 97,025 & 102,764 & 126,681 & 118,831 \\
\hline \multirow{3}{*}{$\begin{array}{l}\text { 非 } \\
\text { 食 } \\
\text { 唃 }\end{array}$} & 洗剤, シャンプー & 11,358 & 11,515 & 11,830 & 11,801 & 14,472 \\
\hline & 化 & 1,451 & 2,294 & 2,495 & 2,740 & 3,354 \\
\hline & 医薬品、その他 & 1,960 & 1,662 & 1,205 & 1,963 & 1,847 \\
\hline \multicolumn{2}{|c|}{ 合 } & 125,755 & 137,107 & 146,744 & 175,823 & 172,830 \\
\hline \multicolumn{2}{|r|}{ 第二種指定製品合計 } & 107,622 & 115,991 & 123,798 & $\begin{array}{l}3 \mid 150,282\end{array}$ & 142,110 \\
\hline
\end{tabular}

第二種指定製品とは醬油，酒類，清涼敛料用をいう。

○米国におけるボトル用 PET 樹脂の需要

(単位：1000トン)

\begin{tabular}{|c|c|c|c|c|c|}
\hline & 1991 & 1992 & 1993 & 1994 & 1995 \\
\hline 清涼飲料他 & 544 & 631 & 715 & 837 & 1,099 \\
\hline
\end{tabular}

出所：モダンプラスチックス誌（平成 8 年 1 月号）

○欧州におけるボトル用 PET 樹脂の需要

(単位：1000トン)

\begin{tabular}{|c|c|c|c|c|c|}
\hline & 1991 & 1992 & 1993 & 1994 & 1995 \\
\hline 清涼飲料他 & 432 & 485 & 510 & 585 & 794 \\
\hline
\end{tabular}

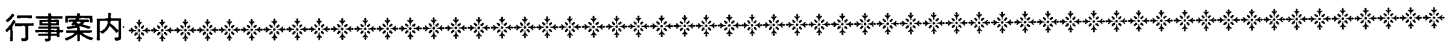

第29回日本水環境学会セミナー（実習セミナー）のご案内 「水試料の変異原性試験」

主催：(社)日本水環境学会

水道水をはじめ, 下水処理水や産業排水の安全性 評価のための新しい方法の一つとして, Ames 変異 原性試験が注目されている。しかし，この試験方法 を効率的に行い，再現性良く，定量的な結果を得る ためには，いくつかの注意点がある.

本セミナーでは，水道水および排水を用いて試料 濃縮操作, Ames 変異原性試験操作及び試験結果の 整理と評価の方法等についての講義と実習および討 論を行い,「水試料の変異原性試験のノウハウを身を つけられるようにする」ことを目的とする。

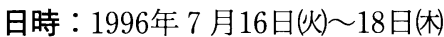

場所：横浜国立大学工学部安全工学棟

$\mathrm{J} \mathrm{R}$ 横浜駅よりバス20分，相鉄線上星川駅 または市営地下鉄三沢上町駅から徒歩 20 分 横浜市保土ヶ谷区常盤谷156 TEL.045-335-1451(代)

参加費：会員 50,000 円 非会員 80,000 円 人数 $: 20$ 名程度 (先着順)

申込先：(社日本水環境学会 セミナー係 TEL 03-3351-2272 FAX 03-3351-2317 